Distancias justas y distanciamientos en Diario de Perlov Hernán Khourian

Arkadin (N. ${ }^{\circ} 8$ ), e006, agosto 2019. ISSN 2525-085X

https://doi.org/10.24215/2525085Xe006

http://papelcosido.fba.unlp.edu.ar/ojs/index.php/arkadin

Facultad de Bellas Artes. Universidad Nacional de La Plata

La Plata. Buenos Aires. Argentina

\title{
DISTANCIAS JUSTAS Y DISTANCIAMIENTOS EN DIARIO DE PERLOV ${ }^{1}$
}

\section{Optimal Distances and Estrangement in Diary of Perlov}

\author{
HERNÁN KHOURIAN \\ wasiberran@gmail.com \\ Instituto de Investigación en Producción y Enseñanza del Arte y Latinoamericano. Facultad de Bellas Artes. Uni- \\ versidad Nacional de La Plata. Argentina
}

Recibido 9/2/2019 | Aceptado 27/5/2019

\section{RESUMEN}

Este artículo aborda Diario (1983), de David Perlov, como un hito patente en el itinerario latinoamericano que representa la preeminencia del documental como ensayo de las últimas décadas. Analiza la fenomenología del documentalista, las evidencias del entramado - un sistema de signos que entablan un diálogo vinculante con la (auto)puesta en escena $-y$ la estrategia discursiva e intertextual, entre el rodaje y el montaje. Señala la invención asociativa, la yuxtaposición de ángulos y de puntos de vista en relación con la visión del cineasta marcada por la errancia, el deseo identitario y el choque con lo heterogéneo que definen una distancia doble, virtual y poética, generando paradojas y tensiones latentes entre lo visible y lo invisible.

\section{PALABRAS CLAVE}

Cine; documental; ensayo audiovisual; autor

\begin{abstract}
This article studies David Perlov's Diary (Yoman) as a clear milestone in a Latin American itinerary that prefigures the preeminence of the documentary as an essay in recent decades. The text focuses on the phenomenology of the documentary filmmaker, the evidence of the framework, a system of signs that engage in a binding dialogue with the (self) staging, the discursive and intertextual strategy, between filming and editing. The author points out the associative invention, the juxtaposition of angles and points of view in relation to the vision of the filmmaker marked by wandering, identity desire and clash with the heterogeneous that define a double, virtual and poetic
\end{abstract}

1 Los desarrollos de este artículo se originan en el proyecto de investigación de tesis (en curso) llevado a cabo por el autor para el Doctorado en Artes de la Facultad de Bellas Artes, Universidad Nacional de La Plata. 
En las últimas décadas, el ámbito audiovisual de Latinoamérica asiste a la producción de obras que confluyen en prácticas ligadas al ensayo, lo que genera la invención de un régimen estético en busca de un sistema abierto y performativo. En muchas de esas realizaciones concurren cuestiones que reencontramos en varios aspectos de la obra Diario (1983), ${ }^{2}$ de David Perlov, en especial, acerca del vínculo del cineasta ensayista consigo mismo y con su entorno, fundamentalmente en cuanto Perlov toma el acto de creación como una experiencia procesual, un cine en proceso.

En este sentido, entendemos que el halo enigmático que envuelve a Diario radica precisamente en la decisión del cineasta de realizar un diario personal teñido de autorretrato, que constituye un ensayo único en sus modalidades ya que fue realizado a lo largo de una década (1973-1983). En tanto ensayo esta obra deja evidencias de las dificultades del armado de un sistema de signos y revela, de ese modo, los procesos que se tensionan por sus propias enunciaciones. Conforma una práctica audiovisual ligada al presente, al cine del presente, un retorno a lo real, y sus formas enunciativas se vinculan a la puesta en escena en abismo, suscitando un diálogo, una estrategia discursiva e intertextual de los diversos aspectos de la realidad que el montaje y el rodaje van estableciendo y desmontando. Es que la obra se va nutriendo de los hallazgos descubiertos en la práctica de los días, lo que hace posible percibir y apreciar cómo la creación de imágenes es atravesada por la invención de una forma asociativa, yuxtaponiendo ángulos y puntos de vista, imaginando diariamente los escenarios, los personajes y las situaciones potenciales [Figura 1].

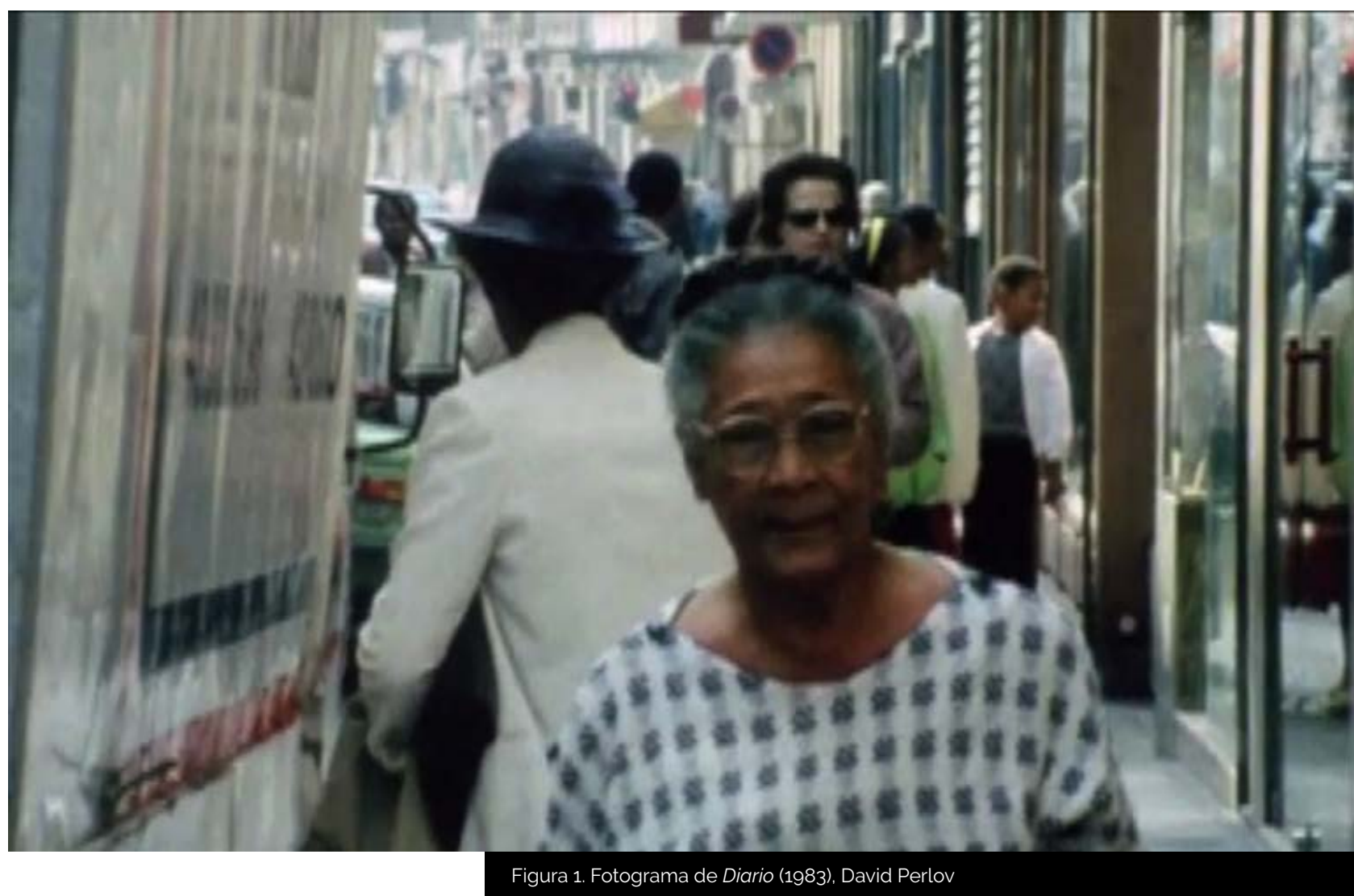

2 Diario es la obra del cineasta brasileño David Perlov, nacido en Río de Janeiro y devenido israelí donde decidió radicarse en 1958. El rechazo de sus propuestas por demasiado líricas por parte de las autoridades de la radiodifusión y el cine israelí lo decidieron a adquirir una cámara de $16 \mathrm{~mm}$ para emprender la grabación de su vida diaria a lo largo de 10 años, en el país que había elegido y que atravesaba la convulsión de posguerra. Diario es la obra que realiza durante la década que se extiende entre 1973-1983. 
Dado que la imagen es un encuentro con lo desconocido, la obra retrata y objetiva la conciencia subjetivante, anudada entre sí por un posible vínculo, un recuerdo, una presencia, una relación entre los sujetos retratados, la cámara y el realizador. Esto se vincula con la observación de Maurice Blanchot (2002) al referirse a la fascinación y explicar que sucede cuando lo que se ve se apodera de la vista, donde la mirada se inmoviliza en luz y esta última es el resplandor de un ojo que no se ve, pero no deja de ver porque es nuestra mirada, nuestra propia mirada en espejo. Sin embargo, el autor advierte que esa luz también es abismo, es «horrorosa y atractiva» y hace que «nos abismemos en ella» (Blanchot, 2002, p. 28).

A partir de lo que sostiene Blanchot, es natural que nos interroguemos acerca de cómo es posible evidenciar las contradicciones de lo invisible, de lo inimaginable. A las imágenes las tenemos que habitar, que personificar, mirarlas y escucharlas para sacarlas de su estado vacuo. Es necesario incluso implicarnos físicamente en una mezcla de intuición y peligro. 0 , al menos, practicar cierta modestia por lo real y tener un deseo de acercamiento, aunque nos separe un abismo. Decir «yo», «tú», «nosotros», «ellos». Respirar (observar, elegir) y sumergirnos en un mismo universo expuesto, expresando la alteridad, formando parte a través de una distancia, de una atención analítica de los presentes, de un tejido singular formado por diferentes «yo soy otro(s)». Por eso quizás nos surge, también naturalmente, la evocación de Arthur Rimbaud (1995) cuando exige: «Digo que hay que ser vidente, hacerse vidente. El poeta se hace vidente por un largo, inmenso y razonado desarreglo de todos los sentidos» (p. 116). A propósito de esto, recordemos que la centralidad de Rimbaud para la modernidad parece resumirse en su legendaria frase «yo soy otro». No obstante, si evocamos esa videncia moderna es porque se aproxima a la actitud de Perlov, cineasta en sus comienzos, un moderno que se afirma en sus primeras obras, ligadas a prácticas industriales, pero que en el pasaje que realiza a lo contemporáneo (a Diario) se desvanece en sus paradojas y contradicciones. La identidad ya no es capturable ni en un «yo» ni en un «yo soy otro» trascendente. En la subjetividad capturada de la autoinscripción, el sujeto es objeto de la mirada por los vaivenes performáticos que se intercalan con un deseo de lo real; su corrimiento es una esquicia de la realidad. El cine concilia esa paradoja ontológica de creer en una ilusión. Quizá porque, como dice Catherine Russell (2011), la autoetnografía es el vehículo y la estrategia que permite cuestionar formas impuestas de identidad y también explorar las posibilidades discursivas de subjetividad no auténticas (p. 446).

Consideramos que Diario es un caso paradigmático de otro cine posible, ajeno a los cánones de la industria, una pieza anticipatoria de la época posmoderna marcada por la incredulidad de los grandes relatos. Apuntamos también que, al partir de irrealidades que se exponen como experiencias de mundos distópicos por el descreimiento y la crítica del estado de situaciones sociales y/o culturales del contexto, dicha obra se exhibe desde una poética confrontativa y obtusa.

Tales visiones suscitan lo visible desde experiencias intersubjetivas buscando los inconvenientes o inadecuaciones del sentido, sus accidentes; inventando nuevas modalidades para captar lo premonitorio y significativo, redescubriendo objetos olvidados y sujetos inadvertidos. En relación con lo señalado, compartimos con Ilana Feldman (2017) la advertencia de que en esta obra de Perlov la equivocación, el trauma de la infancia, «la sensación de estar exiliado en el país que voluntariamente escogió como hogar» (p. 5), junto a la necesidad del luto, al compromiso político con lo cotidiano y a lo que la autora llama una «ausencia fundadora» (p. 5) -que concibe como la búsqueda permanente por la ausencia de un origen tanto en el cine como en el arte-, constituyen figuras de una enunciación subjetiva y de una narrativa en tránsito constante. De este modo, el desplazamiento configura mucho más que un fenómeno geográfico porque, concluye Feldman (2017): 
[...] hace el paso de la identidad a la alteridad, desde la casa a la calle, singular al colectivo, del trauma al duelo, del privado al político. En ese movimiento, su autobiografía - abierta, como una ventana, al afuera- se convierte en biografía del otro, o «alterbiografía», biografía de todos nosotros (pp. 4-5).

En efecto, lo podemos notar a lo largo del film si observamos cómo el realizador, que está ensayando un cine solitario e independiente, con libertad expresiva, va explorando una visión otra atravesada por una errancia que devora las fronteras de géneros e instituciones, que confía en su deseo identitario y enfrenta el choque mismo con lo heterogéneo. Esto nos devuelve al eje de la distancia y entonces recordamos también la evocación de la imagen aurática de Walter Benjamin (1999) como una relación de poder y atracción, «la distancia como un choque» (pp. 152/163), que tiene la particularidad de alcanzarnos, de tocarnos. Al retomar esos conceptos, Georges Didi-Huberman (1997), por su parte, nos aporta una clave de análisis y sugiere que cuando algo nos toca de improviso, lo que hacemos es abrirnos a una dimensión esencial de la mirada, y esa dimensión de la mirada hace que mirar se convierta en el juego asintótico de lo cercano (hasta el contacto, real o fantasmático) y lo lejano (hasta desaparecer y perderse, reales o fantasmáticas). Entonces, al menos, la distancia es doble y virtual, un juego de errancias que revela plano tras plano la subjetividad del cineasta en búsqueda de la propia singularidad e individualidad (autorretrato) y su entorno (retrato), que conforma este ensayo desde la concepción de un cine imperfecto, incompleto y libertario.

La emoción es el cuerpo-social que se desenvuelve frente a nosotros como una estela, un velo que nos absorbe y mira, como Cronos mira el tiempo, un lapso, un fragmento, una totalidad de sensaciones de permanencia, de sucesión. El espacio vive en el tiempo, uno dentro de otro descansa, muere y se despierta en otro movimiento. Lo que se capta es lo que fluye, lo que fluye es lo que se escapa y pareciera irreal, único e irrepetible. A propósito, en una entrevista con François Niney (1992), el cineasta Artavazd Pelechian confiesa que el misterio del montaje a distancia es la posibilidad de que una imagen no real aparezca, que se trata de un flujo y reflujo porque implica un movimiento del nacimiento a la muerte, pero también de un movimiento inverso: crecimiento-degradación, muerte-resurrección. Pelechian, tras afirmar que nadie ha hecho un montaje con imágenes que no existen, sincera lo que él intenta realizar en la arquitectura de sus películas (Niney, 1992). En este fluir azaroso - del tiempo y del flujo continuo de la vida- encontramos el enigma del espectador/autor escuchando sin dejar de poder escuchar, haciéndose eco como un testigo, mirando sin poder dejar de mirar, al igual que algunas veces podemos sentir el dolor antes de percibir la herida.

Ese juego primitivo del cine -iba a decir, ese fuego- es la impresión de realidad. Por algo es que Blanchot (2002) habla de la fascinación como la pasión de la imagen y puntualiza la relación entre imagen y distancia. Si para ver es necesaria la distancia y decidir lo que separa supone el poder de no estar en contacto y evitar la confusión que conlleva, la fascinación, sin embargo, implica que ver convierte la separación en encuentro. Esto lo lleva a Blanchot (2002) a preguntarse qué ocurre cuando lo que se ve, aún a distancia, parece tocarnos, es una especie de toque y se impone a la mirada «como si esta estuviera tomada, tocada por la apariencia» (p. 27). Finalmente, sostiene que la imagen es lo que nos es dado por un contacto a distancia y define la fascinación como la pasión de la imagen.

En Diario se plantea un espacio-tiempo paralelo ligado al espectador que confronta la película con un bloque en presente, el tiempo del sujeto-autor filmado será semejante al vivido por el espectador, de modo tal que el documental busca esa duración, esa vivencia comprometida con lo real, con todo lo que esto conlleva en relación con la mirada con y desde el espectador en una misma realidad viviente y espectral. El espectador debe realizar la tarea que Jacques Rancière (2010) describe paso a paso: observa, selecciona, compara, interpreta y va ligando lo que ve con muchas otras cosas que ha visto en otros lugares como si compusiera su poema con elementos del poema que tiene delante. Es decir, el 
espectador es partícipe de la perfomance rehaciéndola a su manera para hacer de ella una pura imagen y asociarla a una historia que ha leído o soñado, vivido o inventado. «Así, son a la vez espectadores distantes e intérpretes activos del espectáculo que se les propone» (Rancière, 2010, p. 19).

Sin embargo, como las relaciones en lo contemporáneo se complejizan, mutan los vínculos, se amplía la brecha y la nitidez del espacio-tiempo se ve claramente distorsionada, expandidos uno sobre otro, asistimos a estratagemas y disposiciones que estimulan la repetición y el instante, lo que induce a preguntarse si se trata de una subjetividad que toma conciencia de la dialéctica de lo inmediato. Estamos ante un proceso de transformación, de subjetivación, que busca particularizar la deriva. Es decir, estamos en presencia de una dialéctica confidencial que parte de las cosas, pero no para subrayarlas, sino para verificarlas hipotéticamente en directo, indagándolas. Y eso tiene que ver con la enunciación que procede buscando sorpresa e improvisación, confrontando y debatiéndose sobre la decisión tomada, vivenciando los signos.

De este modo, no es preciso interrogarse tanto sobre las imágenes, como con o entre ellas, pues su valor político recae mucho más en la posición de la enunciación que en el contenido del enunciado. Desde estas prácticas relacionales, las imágenes resisten, cuestionan las relaciones entre dominación y emancipación, e interrogan categorías de acción y de producción. En esta lógica, como veremos a continuación, Perlov ensaya poéticas que reflexionan sobre el dispositivo fílmico y proponen estéticas intersticiales para articular vértices entre las múltiples capas de la experiencia personal, el pensamiento crítico, el sentido de pertenencia colectiva, la evidencia de lo real, el propio acto de filmar y las relaciones entre pasado y presente, entre ausencia y presencia, entre memoria y olvido (Lagos Labbé, 2018).

De esa elección, de sus impresiones, se desencadenan palabras, textos e imágenes que se van declinando más allá de los primeros sentidos. Se crea una configuración de ideas espontáneas en paralelo a la percepción de los acontecimientos, una desviación entre acción y percepción, según la cual se vivifican distintas versiones imaginadas, espacio-temporales derivadas, de las mismas situaciones, una serie infinita de realidades. En la imagen resultante de la experiencia, el yo está disuelto siempre en una reconstrucción de sus límites. Mirando la imagen de este modo se pierde el vínculo superficial entre figura y fondo, se disuelven sus contornos y se obtiene un estado de fusión, que mira la captación de la experiencia en sí misma, donde encuentra su pasaje al entorno de las imágenes. Es así como se instala un sistema creado entre invención y memoria, un espacio inquieto entre palabra e imagen que provoca rarificaciones en las escenas y en los escenarios, despegando las imágenes de los fondos. Esto tiene relación con lo que Daniel Belinche (2011) señala al referir que la perspectiva conquistada monta un dispositivo incorporando el fondo en la mirada y en la escucha, es decir que incluye lo que está oculto, repara lo que está detrás en un paso que implica decisiones de percibir y estrategias de composición [Figura 2]. Este señalamiento de la perspectiva por parte de Belinche precede a la mención de la tesis que aporta Ricardo Piglia, quien en Formas Breves (2000) sostiene que todo cuento plantea al menos dos historias: una evidente y otra cifrada; una en la superficie del relato y otra en sus intersticios.

EL PACTO «FANTASMÁTICO» Y LA PUESTA EN ABISMO 


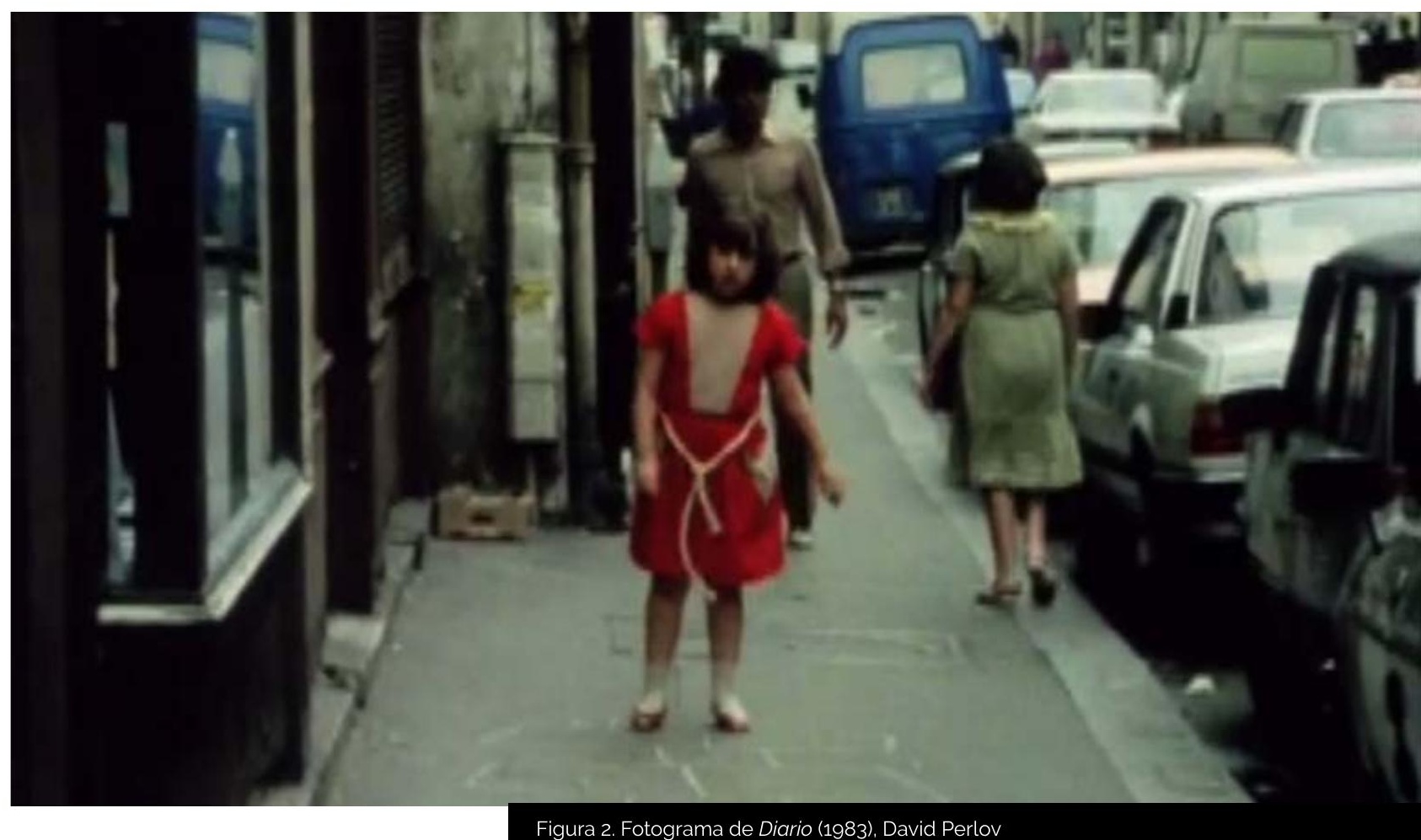

Si seguimos la huella de Piglia (2000) nos aproximamos a una perspectiva que trabaja al menos en dos lecturas de relatos simultáneos: la de la superficie y la de los intersticios. En nuestro caso, esa perspectiva es posible al acercar los fondos y alejar las figuras y, muchas veces, al buscar dichos intersticios unos sobre otros, cortando y despegando las partes como si fuese un montaje por décollage, mientras encontramos las diferencias entre las partes, sus suturas y semejanzas donde se reúnen los labios de una herida. Así, notaremos que los sucesos y sus verdades aparentes (el efecto de lo real) se componen de múltiples planos (lecturas) como cualquier intento de ensayo, rompiendo una perspectiva unívoca, despegando de un punto de vista centralizado, desintegrándose para transformarse en espectros de lo real.

Las imágenes turbadoras entran en el terreno de las visiones fantasmales, de los sueños de las realidades. Por eso, el acto de creación es una invención política, liberadora de nuestro imaginario. Al excavar lo oculto y envuelto, se observan las posibles apariciones, se exponen las imágenes que pasaron inadvertidas, los cuerpos singulares, los rostros entregados a otros, a la dicha del encuentro que suscita lo visible, la fantasmalidad y lo ubicuo. Para Edgar Morin (2001) se trata de un sistema complejo de credibilidad y participaciones que se interrelacionan para definir cada tipo de ficción. Así, esta se define por la libertad y la violencia de las proyecciones, identificaciones imaginarias con lo real. «El realismo es la apariencia objetiva de la fantasía» afirma Morin (2001, pp. 149-150).

Gonzalo de Lucas (2007) considera que esos diarios serían «una especie de meditación sobre el bosquejo o el apunte, sobre el gesto del esbozo. También un gesto de amargura y rabia» (p.63). Se refiere De Lucas (2007) a lo que llama las «edades de la película» (p.63), señalando las etapas de la 
creación en lo que resume como «Un ciclo visible, suave y rugoso como la piel cambiante de una fruta» (p.63) y que, coincidimos en entender, se evidencia en Diario con nitidez:

Después vendría el descubrimiento del lenguaje y sus juegos, los entusiasmos y, más tarde, las progresivas dudas, las épocas oscuras e introspectivas, la serenidad, las despedidas. Las edades de una película poseen su cuerpo y sus gestos, desde la agilidad de los primeros años (es el lado aéreo y elástico de los camarógrafos) hasta la lentitud, la fatiga, la melancolía de la madurez (es la gravedad de la cámara) (De Lucas, 2007, p. 63).

En Diario asistimos a una puesta en abismo en directo que plantea ciertos interrogantes ligados al tiempo-espacio como virtualidad, registrando distintas zonas afectivas en una misma escena trastocada, escindida. Esto puede observarse claramente en el film, por ejemplo, hacia el final de la parte cinco. Perlov está llegando al aeropuerto para ir de París a San Pablo. Vemos imágenes del aeropuerto tomadas desde un taxi [Figura 3]. Su voz en off lo expresa significativamente:

Les pedí a Yael y a Naomi que no pidan licencia en el trabajo.

Que no vengan al aeropuerto. «Está bien», dije. «Sao paulo queda a la vuelta de la esquina». «El avión vuela como un pájaro».

No parecen entenderlo. Para ellas, los pájaros vuelan como aviones. ¿Dónde están hoy los pájaros? ¿Qué le sucedió al albatros? ¿Dónde está la puerta de embarque a Sudamérica? ¿A Sao Paulo? Deseo encontrarme en Brasil (Perlov, 1983, 00:53:35)

La obra existe obrando sus imágenes, traduciendo un diálogo en una lengua extranjera, simbólicamente

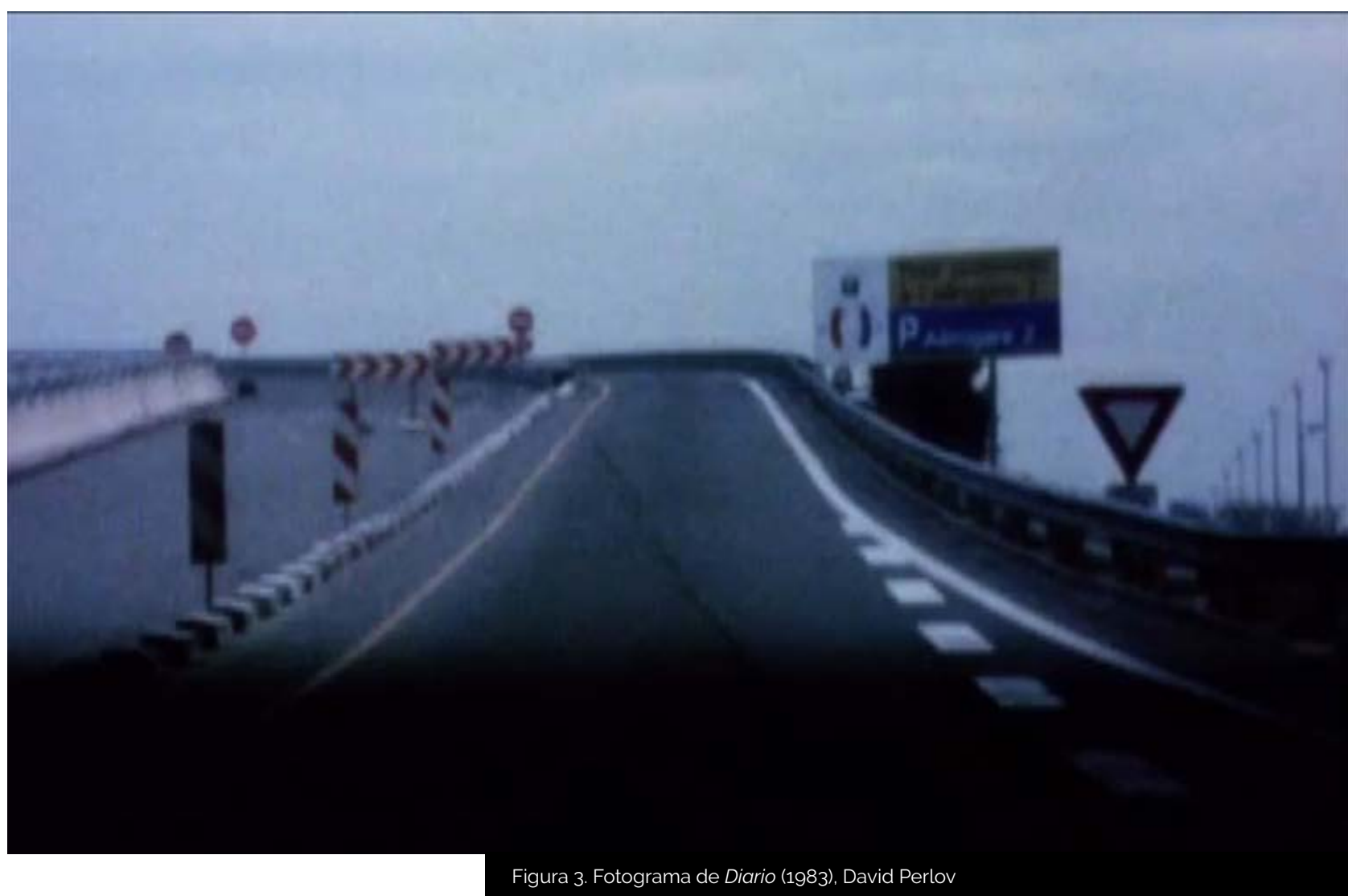


inexplicable, una conversación diferente entre palabras e imágenes, vinculando lo inteligible y lo sensible, elaborando y exponiendo un régimen de apariciones que cuestiona los mecanismos de construcción de imágenes y discursos. Y también, un cierto modo de lectura-escritura de las imágenes, del mundo de las imágenes y sus imaginarios, y de cómo habitarlos políticamente.

Es válido recordar entonces que todo tipo de práctica cinematográfica es ficcional ya que siempre será parcial y subjetiva, histórica y socialmente determinada. Por eso, las imágenes tomadas en Diario son cortes dinámicos, visiones sin afanes aclaratorios y/o explicativos, son más bien llevadas a cabo por una turbia limpidez que depende de una opacidad concienzuda, de una poética. Dicha opacidad es el carácter subdeterminado de su poder hacer ver y constituye en el modo mismo de la presentación sensible que es inherente al arte. Como dice Rancière (2011): «La palabra representada es golpeada por la pasividad de lo visible que paraliza la acción y absorbe las significaciones» (p. 129).

Después de apuntar las estrategias señaladas, podemos decir que el campo y el fuera-campo perlovianos pertenecen ambos a un mismo universo imaginario, «de fantasía», como diría Morin (2001, p.149), entre transmutaciones y remolinos en los que se sueldan sueño y realidad. Se actualizan todo el tiempo en una confrontación con lo transhistórico, en una maniobra que es reversible, ya que vehiculiza y recomienza cada vez sobre sí «un espacio imaginario» (p.150), articulado como encuentro y travesía, para evidenciar las marcas y las suturas de la escena fílmica.

Podemos retrotraernos a una de las primeras preguntas que se hace el realizador en la obra para aprehender y comprender lo que hace en Diario. Para ello es interesante que tengamos en cuenta lo que advierte Raymond Bellour (2009):

\footnotetext{
¿Quién soy yo? Responden haciendo de ese «yo», a veces apenas percibido, un ser de dispersión, de exceso, de deriva, de juego, y el soporte visible de un anonimato que prepara un acceso, tanto a la captación del mundo como a las fuerzas de la inquietud personal. Vemos sujetos atraídos desde lo más íntimo de ellos mismos hacia una forma nueva de «pensamiento de afuera», a partir de las exigencias y de las posibilidades de la imagen y el sonido (p. 337).
}

Los procedimientos tensionan lo que procesan entre lo individual (autorretrato) y lo contextual (retrato) para darle un sentido de visión a la realidad. Observando a los semejantes, a los otros y a sí mismo, Perlov permite al espectador comprender su extraterritorialidad, la que señala como cotidianeidad en imágenes simples, frágiles frente a los otros, a la comunidad y su familia. Ambos captados dificultosamente en un juego doble del registro de su cuerpo, reflejando las marcas de enunciación que recorren su autoinscripción, una y otra vez como una caja de resonancia y disonancia del mundo que lo rodea.

Es necesario que destaquemos el hecho de que, tratándose de una obra «autobiográfica» y tan extensa como Diario, el autor aparece muy pocas veces delante de la cámara. Esas apariciones, además, se hacen patentes a partir de reflejos segmentados (en espejos, por la voz detrás de cámara, etcétera), pero nunca en una imagen completa, todo lo cual determina cierta cuestión espectral [Figura 4].

En El pacto autobiográfico y otros textos (1994), desde el campo literario y refiriéndose específicamente 


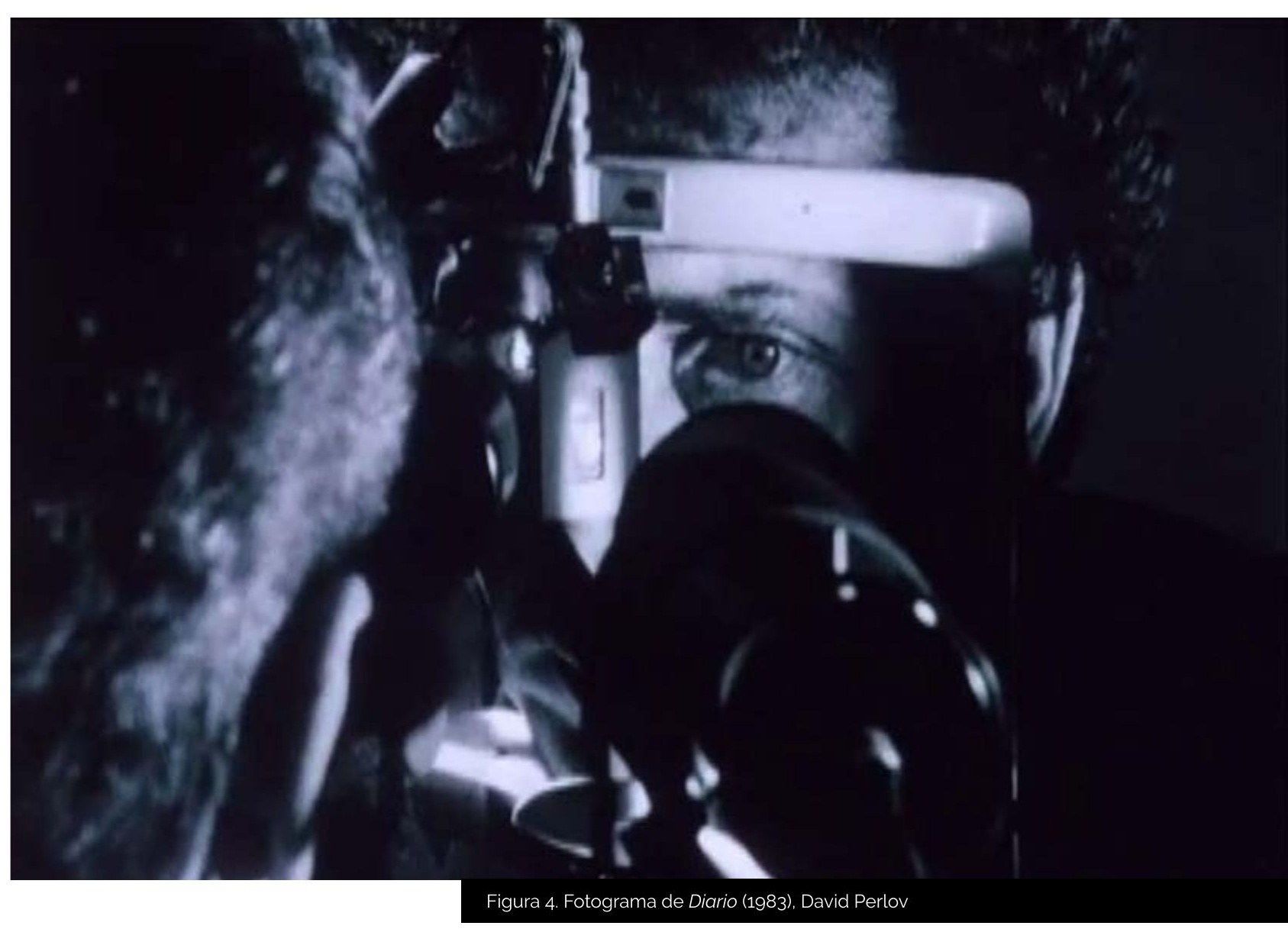

al espacio autobiográfico en relación con la novela, Philippe Lejeune explica en qué consiste esa forma indirecta que llama el «pacto fantásmático» (p.83). En ese texto fundante señala que el lector es invitado a leer novelas no solo como ficciones que remiten a una verdad sobre la naturaleza humana, sino también como fantasmas reveladores de un individuo (Lejeune, 1994, p. 83). Tiempo después de ese ensayo, donde abordaba con exclusividad el pacto fantasmático en la novela, Lejeune (2008) extiende su interés por lo autobiográfico para investigar el fenómeno en el cine. Su acercamiento a una posible definición de lo autobiográfico en el cine plantea una problematización de los conceptos y términos al escrutar las diferencias entre la novela y el cine para presentar el reparto íntimo, privado y público. Entiende que el cine autobiográfico comienza a existir de una forma distinta a la autobiografía escrita, pero también diferente a la del cine de ficción, por lo que lo considera «a mitad de camino entre el cine amateur y el cine de ensayo» (pp. 16-24).

No es difícil admitir, pese a las diferencias procedimentales, que el autorretrato filmado en Diario se elabora desde dicho pacto fantasmático, puesto que trabaja sobre la imagen que da el artista de sí mismo y de sus reflejos en las sombras de lo real, a través de la fuerza de un estilo dado por una ética y una estética comprometedoras que, pese a todo, se deja trabajar por el propio mundo de las imágenes alteradas, en abismo. El presente es suspendido en el aire, se desplaza y abre desde un pasado a un futuro próximo, enriqueciendo todas sus potencialidades, tanto futuras como pasadas. $Y$ cuando nos interrogamos de qué modo se entrelazan, pensamos en la posibilidad de esa zona obtusa, en un intervalo sin fin entre aprehensión e imaginación. Como si se hubiera propuesto auxiliarnos a resolver 
esa cuestión, nos aclara Gilles Deleuze (1990) que así como no hay presente que no esté poblado por un pasado y un futuro, tampoco hay un pasado que no se reduzca a un antiguo presente, no hay un futuro que no consista en un presente por venir.

\footnotetext{
La simple sucesión afecta a los presentes que pasan, pero cada presente coexiste con un pasado y un futuro sin los cuales él mismo no pasaría. Al cine le toca captar este pasado y este futuro que coexisten con la imagen presente. Filmar lo que está «antes» y lo que está «después» (Deleuze, 1990, p. 60).
}

Si el gesto moderno rosselliniano por excelencia consistía en filmar la espera, en el pliegue contemporáneo que propone Diario lo que se monta filmando es la soledad del sentido inacabado, una suspensión, un desdoblamiento errático que conduce a una desviación como forma poética, el antes y el después de la fabricación de una imagen que intenta resistir el embate de lo imposible: la dificultad del vínculo con lo otro y la historización de los lazos sociales. Se trata del método que Fredric Jameson (2012) llama «desreificación», que se adecua a la observancia perloviana. Jameson (2012) lo entiende como «un cortocircuito de todos los cables del inconsciente político» (p. 134), un intento de purgar los contenidos residuales de la fantasía colectiva y la representación ideológica.

La mirada de lo que sucede, la duración del sentido, se tensiona con la literalidad de los hechos, los acontecimientos en cine se construyen desde las distancias entre lo que vemos y nos mira en una (auto) puesta en escena, en una especie de cortocircuito fugaz entre lo cercano y lo lejano. Las imágenes (des)componen las realidades, pero no de manera rígida y estática, sino en proceso permanente, dispersas. En Perlov, el campo (visible) de la imagen piensa el fuera de campo, imagina lo invisible, lo vuelve presencia y lo comunica descomponiéndolo como murmullo y persistencia, haciéndole hoyos, haciéndole mella a los sentidos, presentando lo ausente como suposición del presente. Pascal Bonitzer (2007) describe el desarrollo del proceso en estos filmes donde el cine vuelve sobre sí mismo intentando aferrar el objeto-causa: la mirada imaginada al campo ausente. Y sucede que «la mirada que viene del campo ausente es una puesta en escena paranoica y no juega como el elemento oculto y secreto de la tensión del campo» (Bonitzer, 2007, pp.75-76). Al contrario, la mirada se convierte en el objeto mismo del juego cinematográfico: «El espacio cine se revela agujereado y lo que vuelve a través de esos agujeros del realismo técnico son los fantasmas de la mirada y de la voz que hostigan y ofuscan los bordes de la imagen» (Bonitzer, 2007, pp. 75-76).

Develary reparar el vacío de quien mira y es mirado, encontrar su articulación, aportar a los imaginarios instituidos una perspectiva que puede estar escondida o no, pero que crea presencias desde las ausencias, huecos, escisiones por donde acceder y entrever para escuchar: Perlov, desde un fenómeno de desconexión y extrañamiento, cuestiona su propia visión y también el lugar que ocupa en el mundo de las imágenes. De ese modo, esboza un imaginario de los afectos perdidos, cenizas subterráneas de una memoria en permanente elaboración. Paola Lagos Labbé (2012) revela cómo se hacen evidentes las estrategias de evocación poética de una «estética del desarraigo o del desamparo» que se conforma transitando entre la filiación y la orfandad.

\footnotetext{
En este constante ir y venir entre el alejamiento y el acercamiento desde/hacia los orígenes. De ahí que no es de extrañarse que los registros de enunciación narrativos sean la reminiscencia, la nostalgia, el desaliento, la fragilidad del recuerdo y el futuro incierto, la «lejanía interior», la saudade que se impregna en los pequeños detalles, gestos e interjecciones (Lagos Labbé, 2012, p. 10).
}

Cumple, de esa manera, la doble función de trabajar sobre lo mediato para liberarlo y recorrerlo como ruinas, al mismo tiempo que incorpora en ese recorrido al espectador que tiene delante de sí la tensión del proceso artístico, de la forma viva y abierta, con todo lo que esto conlleva en relación con la mirada, 
con y desde el espectador. De este modo, el dispositivo es marcado también por el azar de los sujetos impredecibles en el circuito de representación, en el umbral de todo pasaje a lo real.

El desencadenamiento del punto de vista, asumido como un desvío, es una puesta a distancia entre lo visible y lo invisible, una distancia trabajada desde una ilusión perceptiva, elaborada desde una dialéctica del alejamiento como espacio de proximidad (de los otros). Ese es el juego que supone el pacto fantasmático al que Lejeune (1994) puede resumir señalando cómo, por un lado, meterse dentro de los demás para comprender de qué modo lo ven a uno y, por otro lado, ponerse fuera de sí mismo, salirse de uno para verse como si fuera otro. Se trata, en los dos lados, «de un juego falseado, amañado, por una elasticidad en el intento de establecer una distancia total para ser los demás y otro a la vez» (pp. 117-118).

En otras palabras, las imágenes son una alteridad que tenemos que descubrir para contagiarnos, para recibir la multiplicidad de voces, desde una copresencia que contribuye a despertar las distintas perspectivas de una poética de los cuerpos y de las miradas evocadas. Dicho diálogo oculto es legible en las encrucijadas tomadas por la imagen y su reiteración, en ese espacio del sentido y sus variaciones, donde se ensaya una transmisión proyectada en el corazón mismo de las imágenes. Se trata de hacer ver-oír los desvíos posibles, introducirlos -en la cadena de representación- como gérmenes en el tiempo. La película como investigación está estructurada sobre la base de la crónica diaria duplicada, de lo presente y aparente de la prosa, y de la poesía en la búsqueda de sus accidentes. Evidentemente, en esa distancia de la aprehensión de lo real hay algo que se encuentra en su alteración a través de la observación que enfrenta al medio autónomamente, encontrando brechas, modificando el presente, condensando en la voz la búsqueda de hipótesis de partida y de conclusiones supuestas por bloques y secuencias. Así se forma Diario, historizando el presente, sus ruinas y su poetización.

\section{REFERENCIAS}

Belinche, D. (2011). Arte, poética y educación. La Plata, Argentina: Innova.

Bellour, R. (2009). Entre-imágenes. Ciudad Autónoma de Buenos Aires, Argentina: Colihue.

Benjamin, W. (1999). Sobre algunos temas en Baudelaire. Ciudad Autónoma de Buenos Aires, Argentina Leviantán.

Blanchot, M. (2002). El espacio literario. Madrid, España: Editora Nacional.

Bonitzer. P. (2007). El campo Ciego. Ciudad Autónoma de Buenos Aires, Argentina: Santiago Arcos editor.

Deleuze, G. (1990). ¿Qué es un dispositivo? En Deleuze, G., GLucksmann, A., Frank, M., Balbier E. y otros Michel Foucault, filósofo (pp.155-163). Barcelona, España: Gedisa

De Lucas, G. (2007). Diez años en la vida del cineasta David Perlov. La mano y la visión. Cahiers du cinéma, (1), 80. Recuperado de https://issuu.com/bibliocinetica/docs/cahiers_esp_01__mayo_2007_

Didi-Huberman, G. (1997). Lo que vemos, lo que nos mira. Ciudad Autónoma de Buenos Aires, Argentina: Manantial.

Feldman, I. (2017). As janelas de David Perlov: autobiografia, Luto e política [Las ventanas de David Perlov autobiografia, duelo y polítical. Arquivo Maaravi. Revista Digital de Estudos Judaicos da UFMG, 11 (20). 4-14. Recuperado de http://WWw. periodicos.letras.ufmg.br/index.php/maaravi/article/view/11757

Jameson, F. (2012). Signaturas de lo visible. Ciudad Autónoma de Buenos Aires, Argentina: Prometeo.

Lagos Labbé, P. S. (2012). Viajes de ida y retorno entre la pertenencia y el desarraigo. La construcción narrativa del hogar y la identidad en los diarios cinemautobiográficos de David Perlov. Comunicación Revista Internacional de Comunicación Audiovisual, Publicidad y Estudios Culturales, 1(10), 531-546. Recuperado de http://Wwww.revistacomunicacion.org/pdf/h10/mesa3/041.Viajes_de_ida_y_retorno. entre_la_pertenencia_y_el_desarraigo.La_construccion_narrativa_del_hogar_y_la_identidad_en_los_ 
diarios_cinemautobiograficos_de_David_Perlov.pdf

Lagos Labbé, P. S. (2018). Diarios nómades. Poéticas del intervalo para representar el desarraigo en el cine de David Perlov. Archivos de La Filmoteca, (75), 57-84. Recuperado de http://Www. archivosdelafilmoteca.com/index.php/archivos/article/view/637

Lejeune, P. (1994). El pacto autobiográfico y otros textos. Madrid, España: Megazul-Endymion.

Lejeune, P. (2008). Cine y autobiografia, problemas de vocabulario. En Martín Gutiérrez, G. (Ed.), Cineastas frente al espejo (pp. 16-24). Madrid, España: T\&B Editores.

Morin, E. (2001). El cine o el hombre imaginario. Barcelona, España: Paidós.

Niney, F. (1992). Le documentaire est un film [El documental es una pelicula] [Entrevista a Artavazd Pelechian]. Cahiers du cinéma, 454, pp. 35-37.

En Catálogo de la 2da Bienal Europea del Documental, Marsella, Francia. Entretien avec Artavazd Pelechian y reproducida en.

Perlov, D. (Director). (1983). Yoman [Diario] [Película]. Israel: Channel 4.

Piglia, R. (2000). Formas Breves. Barcelona, España: Anagrama.

Rancière, J. (2010). El espectador emancipado. Pontevedra, España: El Lago Ediciones

Rancière, J. (2011). El destino de las imágenes. Ciudad Autónoma de Buenos Aires, Argentina: Prometeo. Rimbaud, A. (1995). Iluminaciones; cartas del vidente. Madrid, España: Hiperión.

Russell, C. (2011). Autoetnografia: Viajes del Yo. laFufa, (12). Recuperado de http://www.lafuga.cl autoetnografia-viajes-del-yo/446 